Michał Jasiński*

\title{
ASPEKTY MONOKULTUROWE POMOCOWEJ CHOROBY HOLENDERSKIEJ
}

\section{Wprowadzenie}

Artykuł obejmuje teoretyczne rozważania dotyczące zagrożeń wynikających ze zjawiska choroby holenderskiej wywołanej przez pomoc rozwojową. Stanowią one pretekst do ukazania ekstremalnego stadium „pomocowej” choroby holenderskiej - określonej na potrzeby tych rozważań „monokulturą pomocową”. Zjawisko to zostało wyróżnione na podstawie analizy wysokości dwóch wskaźników: odsetka oficjalnej pomocy rozwojowej (ODA) w produkcie narodowym brutto (PNB) oraz ODA per capita. Spośród państw o najwyższych wskaźnikach na świecie wyróżniono grupę małych państw wyspiarskich: Federacyjne Stany Mikronezji, Tuvalu, Wyspy Marshalla, Palau, Wyspy Salomona, Kiribati oraz Wyspy Świętego Tomasza i Książęca. Otrzymywanie w długim okresie (i w znacznych ilościach) pomocy rozwojowej, przy jednocześnie utrzymującej się stagnacji gospodarczej w tej grupie państw, sprowokowało autora do próby odpowiedzi na pytania: $\mathrm{w}$ jakim stopniu pomoc rozwojowa przyczyniła się do wystąpienia „monokultury pomocowej” oraz jak trwałe jest to zjawisko. Artykuł stanowi wprowadzenie do dalszych badań zjawiska „monokultury pomocowej".

\section{Pomoc rozwojowa jako czynnik powodujący regres gospodarczy w ujęciu teoretycznym - „pomocowa” choroba holenderska}

Pomoc rozwojowa, w szczególnych przypadkach, może przyczyniać się do wystąpienia choroby holenderskiej. Przybliżając to zjawisko, należy odwołać się do teorii

* Kolegium Ekonomiczno-Społeczne, Szkoła Główna Handlowa w Warszawie. 
handlu międzynarodowego, a dokładniej ujmując do twierdzenia Rybczyńskiego ${ }^{1}$. Zgodnie $\mathrm{z}$ nim „w małym kraju, a więc w warunkach niezmienionych relacji cen na rynku światowym, wzrost zasobów wyłącznie jednego czynnika produkcji, przy niezmienionym poziomie drugiego, prowadzi do wzrostu produkcji dobra zużywającego przede wszystkim czynnik, którego zasoby się powiększają oraz do zmniejszenia produkcji dobra, w wytwarzaniu którego potrzebny jest przede wszystkim czynnik produkcji, którego zasoby nie ulegają zmianie"2. Twierdzenie to stanowi bardzo dobry punkt wyjścia do analizy zmiany roli zasobów czynników produkcji, jakie zachodzą w procesach gospodarczych w poszczególnych państwach. Historia gospodarcza, szczególnie XX w., pokazuje wiele empirycznych przykładów regresu niektórych działów gospodarki spowodowanego zwiększeniem produkcji na eksport ${ }^{3}$.

Regres niektórych działów gospodarki, wynikający ze wzrostu zasobów naturalnych, spowodował powszechne przyjęcie terminu „choroba holenderska”. Określenie to użyte po raz pierwszy w $1977 \mathrm{r}^{4}$ odnosiło się do ciągu zmian związanych z odkryciem i eksploatacją na początku lat 60. ubiegłego wieku w Holandii (na Morzu Północnym) pokładów gazu ziemnego. W 1977 r. państwo to z importera energii netto stało się jej eksporterem. Odkrycie złóż paradoksalnie nie przyniosło trwałych korzyści. Wywołało natomiast silnie destabilizujące zjawiska - wzrost bezrobocia oraz spadek inwestycji. Spowodowało również osłabienie sektora przemysłowego, doprowadzając branżę tekstylną i odzieżową prawie do upadku. Ciąg tych zmian wyraźnie odsłonił słabości gospodarki holenderskiej ${ }^{5}$.

Procesy te można tłumaczyć przy zastosowaniu przytoczonego twierdzenia Rybczyńskiego ${ }^{6}$. Skokowy wzrost zasobów jednego czynnika produkcji (gazu), przy niezmienionych (bądź wolno rosnących) pozostałych zasobach (kapitał, praca), spowodował, że dynamicznie rozwijający się przemysł wydobywczy „wysysał” kapitał i pracę z innych zastosowań. Brak wzrostu (bądź wolne tempo) pozostałych zasobów czynników produkcji powodował, że tylko w ten sposób - „wysysając”, można było mieć do nich dostęp. Kapitał i praca były również niezbędne do zwiększenia wydobycia surowców (budowa szybów czy kopalń, wzrost zatrudnienia).

Mimo że analogiczne mechanizmy, wywołane odkryciem znacznych zasobów surowcowych zaobserwowano również w innych państwach (m.in. w Kanadzie,

1 Szerzej patrz T.M. Rybczynski, Factor Endowment and Relative Commodity Prices, „Economica, New Series" Vol. 22, No. 88, 1955, s. 336-341.

2 A. Budnikowski, Międzynarodowe stosunki gospodarcze, Polskie Wydawnictwo Ekonomiczne, Warszawa 2006, s. 131.

3 Ibidem, s. 132.

4 „The Economist” November 26, 1977, s. 82-83.

D. Kopiński, Pomoc rozwojowa. Teoria i polityka, Difin, Warszawa 2011, s. 17.

6 A. Budnikowski, op.cit., s. 132. 
Meksyku, Norwegii, Wielkiej Brytanii, państwach arabskich czy zdaniem niektórych ekonomistów również w Rosji), to powszechnie w literaturze z zakresu ekonomii międzynarodowej tego rodzaju regresowi, wywołanemu przez gwałtowny wzrost czynników produkcji (nie tylko zasobów naturalnych), przypisuje się termin „choroby holenderskiej”. Przeniknął on również do innych subdyscyplin ekonomii i może dotyczyć m.in. takich zjawisk, jak napływ zagranicznych inwestycji bezpośrednich, związany z początkowym okresem członkostwa w Unii Europejskiej napływ funduszy pomocowych ${ }^{7}$ czy też np. wpływów z tytułu turystyki międzynarodowej ${ }^{8}$.

Głównym zewnętrznym symptomem choroby holenderskiej jest realna aprecjacja waluty krajowej, którą rozpatruje się z perspektywy dwóch równolegle występujących zjawisk: efektu wydatkowego i efektu przesunięcia zasobów (określanego też bezpośrednią deindustrializacją) $)^{9}$. Analogicznie jak w przypadku „surowcowej” choroby holenderskiej, podobnie wywołaną przez pomoc rozwojową analizuje się przez pryzmat dwóch przywołanych efektów. Pomoc rozwojowa może być skoncentrowana nierównomiernie na finansowaniu dóbr i usług niehandlowych, takich jak budownictwo, ochrona zdrowia czy edukacja, które w państwach rozwijających się charakteryzują się szczególnie dużym popytem. Oczekiwanym efektem w tych przypadkach będzie wzrost płac w tych sektorach. Będzie to bodźcem do napływu dodatkowej siły roboczej. Realokacja tego rodzaju będzie kontynuowana do momentu ogólnego wzrostu poziomu płac. Wyższe płace wpłyną ujemnie na dochodowość i konkurencyjność w eksporcie dochodowym. Spowoduje to osłabienie (spadek) eksportu. W konsekwencji jest to typowy dla choroby holenderskiej efekt przesunięcia zasobów. Efekt wydatkowy natomiast wynika z równoległego zjawiska i dotyczy wyższego dochodu i popytu, które zostanie uruchomione przez wyższe płace - podnosząc tym ceny dóbr niehandlowych w relacji do dóbr handlowych. To spowoduje przyciągnięcie firm i zasobów do sektora dóbr niehandlowych, dodatkowo osłabiając sektor eksportowy ${ }^{10}$.

7 Por. Nowa Europa, red. D. Rosati, Instytut Wschodni, Warszawa 2007, s. 124

8 Por. J. Capó, A.R. Font, J.R. Nadal, Dutch Disease in Tourism Economies: Evidence from the Balearics and the Canary Islands, „Journal of Sustainable Tourism” Vol. 15, No. 6, 2007, s. 615-627; M. Jasiński, Zrównoważony rozwój w monokulturowych gospodarkach turystycznych, [w:] Zrównoważony rozwój turystyki, red. S. Wodejko, Oficyna Wydawnicza SGH, Warszawa 2008, s. 218, 219; M. Kachniewska, A. Niezgoda, A. Pawlicz, Globalizacja i internacjonalizacja działalności turystycznej, [w:] Rynek turystyczny. Ekonomiczne zagadnienia turystyki, red. M. Kachniewska, E. Nawrocka, A. Niezgoda, A. Pawlicz, Wydawnictwo Wolters Kluwer Polska, Warszawa 2012, s. 215-222.

9 Por. W.M. Corden, J.P. Neary, Booming Sector and De-industralization in a Small Open Economy, „Economic Journal" Vol. 92, 1982, s. 825-848; W.M. Corden, Booming Sector and Dutch Disease Economic: Survey and Consolidation, „Oxford Economic Papers” Vol. 36, No. 3, 1984, s. 359-380; M. Brahmbhatt, O. Canuto, E. Vostroknutova, Dealing with Dutch Disease, „Economic Premise” Vol. 16, World Bank 2010, s. 1-3.

10 D. Kopiński, op.cit., s. 179. 
Literatura przedmiotu nie daje jednoznacznej odpowiedzi co do wpływu pomocy rozwojowej na wzrost gospodarczy za pośrednictwem realnej aprecjacji kursu walutowego. Można wyróżnić trzy punkty widzenia. Zgodnie z pierwszym przyjmuje się, że przekazywana pomoc w sposób jednoznaczny oddziałuje na kurs walutowy, który umacnia się, wywołując negatywne skutki dla przemysłu pracochłonnego i sektora eksportowego. Zgodnie z drugim nie stwierdza się symptomów choroby holenderskiej w analizowanej grupie państw afrykańskich, które otrzymywały znaczną pomoc rozwojową. Jeśli idzie o trzeci, to argumentuje się, że wpływ realnej aprecjacji waluty na wzrost gospodarczy jest niewielki przy przyjęciu perspektywy długookresowej - choroba holenderska natomiast odnoszona jest zazwyczaj do okresu krótkiego ${ }^{11}$. Środki z pomocy rozwojowej finansują również stronę podażową (inwestycje w infrastrukturę, edukację, ochronę zdrowia), oddziałując na poprawę wydajności gospodarki w długim okresie. Korzyści te mogą równoważyć straty poniesione w zakresie konkurencyjności, na której koncentruje się choroba holenderska. Ponadto istotne jest wskazanie, że poziom dobrobytu mieszkańców państw biednych zależy w znacznym stopniu od poziomu bieżącej konsumpcji i inwestycji, które są finansowane przez pomoc, a nie tylko od poziomu produkcji. Korzyści płynące z dodatkowej konsumpcji mogą być znaczniejsze od strat po stronie produkcji. Podobnie choroba holenderska może nie wystąpić w państwach o niskim dochodzie, gdzie występują nadwyżki nieangażowanych czynników produkcji. Kłóci się to z podstawowym założeniem pierwotnego modelu, w którym zakłada się występowanie pełnego zatrudnienia. Nadwyżki mogą zostać uruchomione do zaspokojenia dodatkowego popytu na dobra niehandlowe wywołanego przez napływ pomocy bez wywoływania stanu nierównowagi. Dodatkowo jest możliwość przeciwdziałania chorobie holenderskiej w państwach rozwijających się dzięki polityce monetarnej (tzw. sterylizacja) ${ }^{12}$.

Realna aprecjacja waluty jako zjawisko nie ma inklinacji negatywnych. Towarzyszy ona wielu państwom, które weszły na ścieżkę industrializacji i ze względu na to zwiększają produktywność, produkcję oraz dochód. Ma to związek z efektem Balassy-Samuelsona ${ }^{13}$, zgodnie z którym wzrost produktywności w sektorze handlowym powoduje wzrost płac w gospodarce, również w sektorze niehandlowym. Ponieważ nie występuje wzrost produktywności - wzrastają również ceny w sektorze niehandlowym. Rośnie ogólny poziom cen i dochodzi do realnej aprecjacji kursu walutowego. Problem w odniesieniu do pomocy rozwojowej polega głównie na zjawisku

11 Szerzej patrz M. Nkusu, Aid and the Dutch Disease In Low-Income Countries: Informed Diagnoses for Prudent Prognoses, „IMF Working Paper” No. 4(49), 2004, s. 14, 15.

12 D. Kopiński, op.cit., s. 179, 180.

13 Szerzej patrz D. Begg, S. Fisher, R. Dornbusch, Makroekonomia, Polskie Wydawnictwo Ekonomiczne, Warszawa 2007, s. 294. 
wyprzedzenia przez realną aprecjację wzrostu produktywności i produkcji w gospodarce. Środki z pomocy finansują dodatkową konsumpcję i inwestycje powyżej poziomu, który umożliwiają wewnętrzne zdolności produkcyjne danej gospodarki ${ }^{14}$.

Zamykając rozważania bezpośrednio dotyczące choroby holenderskiej w kontekście pomocy rozwojowej, należy również dodać, że w przypadku pomocy projektowej niekorzystne zmiany kursu walutowego oraz sam efekt choroby są mniej prawdopodobne. Najogólniej, należy przyjąć, że ryzyko jej wystąpienia rośnie wraz ze wzrostem $^{15}$ : wielkości pomocy, relacji pomocy przekazywanej przez budżet (np. wsparcie budżetowe) w stosunku do pomocy projektowej oraz stopnia wykorzystania pomocy na zakup dóbr i usług wytwarzanych na terenie państwa-beneficjenta. Na przykład pomoc przekazywana na profilaktykę i leczenie HIV/AIDS nie wiąże się z zagrożeniem inflacji czy nadmiernej aprecjacji kursu walutowego, gdyż zostanie w większości przeznaczona na wydatki importowe (leki, sprzęt medyczny).

\section{Zjawisko „monokultury pomocowej” w małych rozwijających się gospodarkach wyspiarskich}

Zgodnie z przedstawionymi rozważaniami strumienie pomocy rozwojowej prowadzić mogą do zniekształceń w gospodarce beneficjenta. Najbardziej ekstremalne wydaje się być „popchnięcie” przez nie do wytworzenia sytuacji, w której pomoc staje się dominującym źródłem finansowania rozwoju, czy też wręcz podstawowym źródłem finansowym funkcjonowania państw-biorców. W takich specyficznych przypadkach można mówić o „monokulturze rozwojowej”.

Za modelowe przykłady tego zjawiska posłużyć mogą m.in. położone na Oceanii: Federacyjne Stany Mikronezji, Tuvalu, Wyspy Marshalla, Palau, Wyspy Salomona, Kiribati czy położone na peryferiach Afryki Wyspy Świętego Tomasza i Książęca - (młode) niepodległe państwa zaklasyfikowane (przez Konferencję Narodów Zjednoczonych ds. Handlu i Rozwoju - UNCTAD) zarówno do grupy najsłabiej rozwiniętych gospodarczo państw świata (Least Developed Countries - LDC), jak i do tzw. małych rozwijających się gospodarek wyspiarskich (Small Island Developing States - SIDS).

\footnotetext{
14 D. Kopiński, op.cit., s. 180, 181.

15 Ibidem, s. 181.
} 


\subsection{Wyspiarski model MIRAB}

Analizując procesy gospodarcze zachodzące na wymienionych obszarach wyspiarskich, $\mathrm{z}$ perspektywy ostatnich 50-60 lat, $\mathrm{w}$ dużym uproszczeniu, można stwierdzić, że zgodnie z twierdzeniem Rybczyńskiego w „małym kraju” (przyjmuje się, że SIDS nie są większe powierzchniowo niż 20 tys. $\mathrm{km}^{2}$ i liczba mieszkańców nie przekracza $1 \mathrm{mln}$ ) w wyniku „Zwiększenia podaży niektórych czynników podaży” (pomoc rozwojowa) „nastąpił regres niektórych działów gospodarki” (rolnictwa, rybołówstwa, rzemieślnictwa).

Odwołując się do dorobku G. Bertrama ${ }^{16}$, ujmując analizowane zagadnienie „monokultury pomocowej” z nieco innej perspektywy, można zauważyć, że w latach 80. ubiegłego wieku na podstawie analizy procesów gospodarczych najmniejszych jednostek regionu Oceanii (Kiribati, Niue, Tokelau, Tuvalu, Wyspy Cooka) wyodrębnił się specyficzny model gospodarowania, określany jako MIRAB (czy też model Bertrama $)^{17}$. Z czasem, wraz ze wzrostem pomocy rozwojowej na świecie, zaczął on pojawiać się w większych państwach (i terytoriach) wyspiarskich - nie tylko pacyficznych. Mimo że samo zjawisko w literaturze zdefiniowane zostało w latach 80 . XX w., występowało już wcześniej - m.in. na wyspie Norfolk w końcu lat 40. ubiegłego wieku ${ }^{18}$.

Samo sformułowanie MIRAB jest akronimem od słów: migration (migracje) - MI, remittances (przekazy) - R, aid (pomoc) - A, bureaucracy (biurokracja) - B, które w najprostszy i najbardziej obrazowy sposób ukazuje zasadę funkcjonowania takiej gospodarki. Dominującymi źródłami gospodarowania są dwa elementy. Pierwszym jest migracja zarobkowa znacznej części mieszkańców wysp do państw o dużo wyższym poziomie rozwoju gospodarczego i przesyłanie (przekazy) nabytych środków finansowych (czy też rzeczowych). Drugim jest otrzymywanie pomocy rozwojowej, do której (wraz z jej wzrostem) potrzebna jest coraz większa liczba urzędników do jej wdrażania (rozrost biurokracji). Tym dwóm głównym elementom towarzyszą również inne - tzw. nowe źródła dochodów ${ }^{19}$ - m.in.: sprzedaż praw strategicznych,

16 G. Bertram jest nowozelandzkim ekonomistą specjalizującym się m.in. w subdyscyplinie ekonomii określanej jako island economics (gospodarka wyspiarska).

17 G. Bertram, R.F. Waters, The MIRAB economy in South Pacific microstates, „Pacific Viewpoint” No. 26(3), 1985, s. 497-519; The MIRAB process: earlier analyses in context, „Pacific Viewpoint” No. 27(1), 1986, s. 47-59; G. Bertram, „Sustainable Development” in Pacific Micro-economies, „World Development” Vol. 14, No. 7, 1986, s. 809-822.

18 Por. M.L. Treadgold, Breaking out of the MIRAB mould: historical evidence from Norfolk Island, „Asia Pacific Viewpoint” Vol. 40, No. 3, 1999, s. 237-244.

19 Szerzej patrz R. Crocombe, The South Pacific, University of South Pacific, Suva 2001, s. 362-379; M. Jasiński, Turystyka a małe gospodarki wyspiarskie, „Zeszyty Naukowe KGŚ SGH” nr 23, Oficyna Wydawnicza SGH, Warszawa 2008, s. 197-199. 
sprzedaż praw do zatapiania odpadów, handel narkotykami, hazard, sprzedaż „symboli suwerenności”, sprzedaż paszportów (obywatelstwa), sprzedaż „listów gwarancyjnych”, rejestracja „tanich bander” oraz transmisja danych i obsługa informatyczna.

\subsection{Wielkość pomocy rozwojowej w wybranych gospodarkach MIRAB}

Analizując otrzymywane wielkości pomocy rozwojowej w Federacyjnych Stanach Mikronezji, na Tuvalu, Wyspach Marshalla, Palau, Wyspach Salomona, w Kiribati czy na Wyspach Świętego Tomasza i Książęcej na przestrzeni ostatnich 20 lat (lata 1995-2014), widać wyraźnie, że środki te, proporcjonalnie do wielkości gospodarki, były bardzo wysokie.

W pierwszym przypadku - Federacyjnych Stanach Mikronezji - państwie stosunkowo młodym (uzyskanie niepodległości w 1986 r.), o niewielkiej powierzchni $\left(702 \mathrm{~km}^{2}\right)$ i populacji $(105,2 \text { tys. w } 2015 \mathrm{r} \text {. })^{20}$ wysokość pomocy per capita wahała się od 612 USD (w 2010 r.) do 1385 USD (w 2012 r.) (patrz rys. 1). Jej skalę odzwierciedla również drugi z zastosowanych na rysunku 1 wskaźników (ODA/PNB), który wahał się w przedziale od 20,8\% (w 2010 r.) do 56,1\% (w 2001 r.). Porównując oba wskaźniki, wyraźnie widać, że pomimo wzrostu otrzymywanych środków pomocowych ich relacja w stosunku do PNB uległa zmniejszeniu.

Rysunek 1. Wskaźniki oficjalnej pomocy rozwojowej (ODA) względem produktu narodowego brutto (PNB) oraz ODA per capita w Federacyjnych Stanach Mikronezji w latach 1995-2014
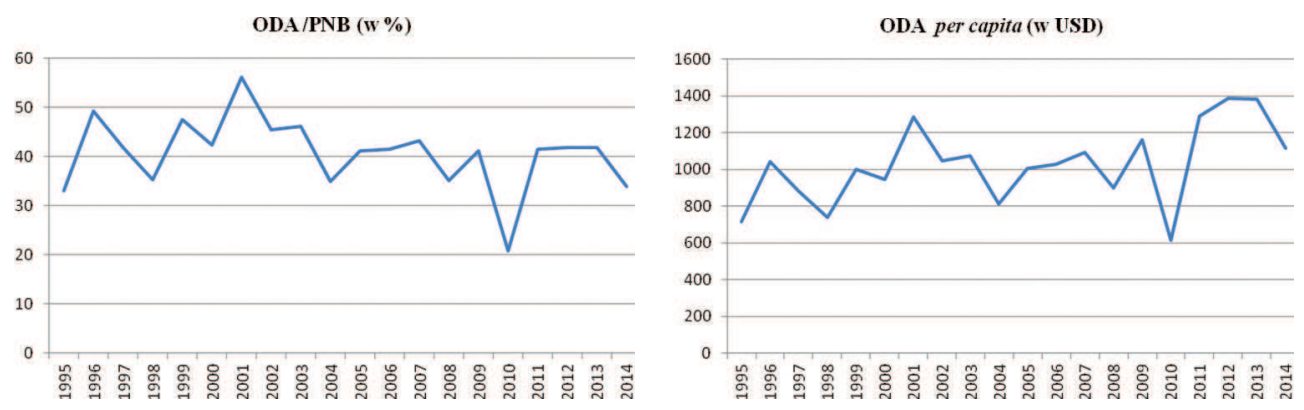

Źródło: Na podstawie danych Banku Światowego, http://data.worldbank.org/ [dostęp 20.06.2016].

Na Tuvalu - w państwie znacznie mniejszym (powierzchnia $26 \mathrm{~km}^{2}$, liczba ludności 10,9 tys. w 2015 r.) i również niedawno powstałym (niepodległość uzyskana

20 CIA The World Factbook, http://www.cia.gov/library/publications/resources/the-world-factbook/ [dostęp 3.07.2016]. 
w 1978 r. $)^{21}$ - pomoc rozwojowa per capita wynosiła od 428 USD (w 2000 r.) do 3950 USD (w 2011 r.). W stosunku do PNB wynosiła do 67\% (w 2011 r.) (patrz rys. 2).

Rysunek 2. Wskaźniki oficjalnej pomocy rozwojowej (ODA) względem produktu narodowego brutto (PNB) w latach 2001-2014 oraz ODA per capita w latach 1995-2014 na Tuvalu
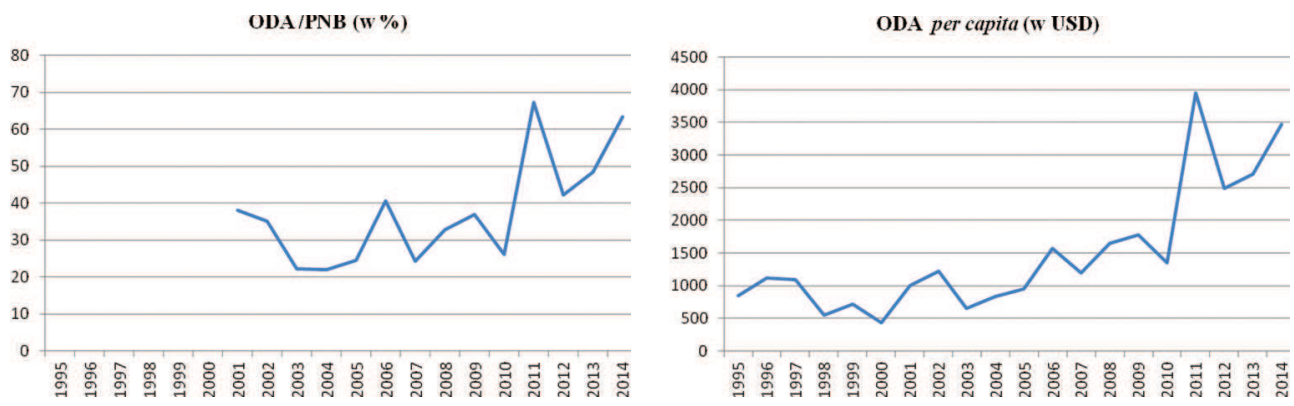

Źródło: Jak do rysunku 1.

Rysunek 3. Wskaźniki oficjalnej pomocy rozwojowej (ODA) względem produktu narodowego brutto (PNB) oraz ODA per capita na Wyspach Marshalla w latach 1995-2014
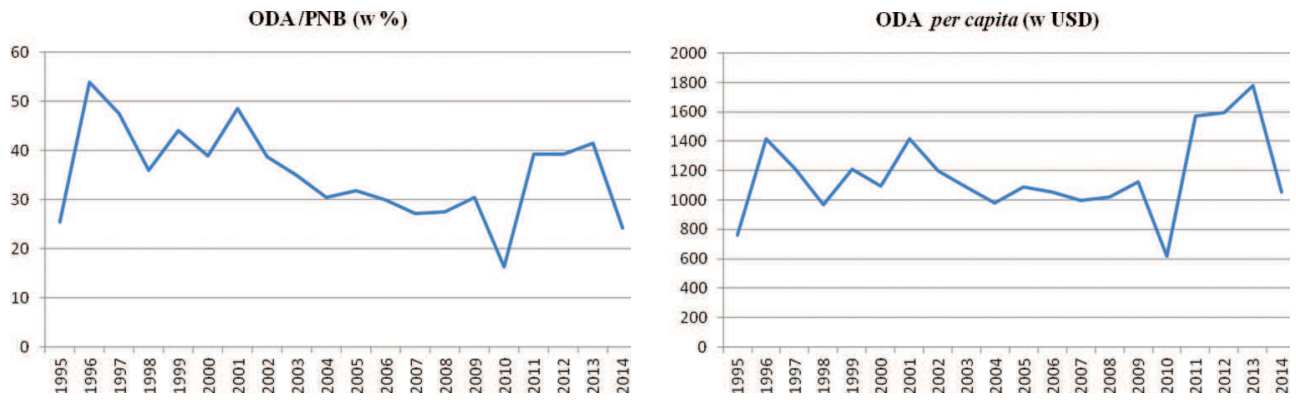

Źródło: Jak do rysunku 1

W kolejnym przypadku - na Wyspach Marshalla (powierzchnia $181 \mathrm{~km}^{2}$, populacja 72,2 tys. w 2015 r., niepodległość uzyskana podobnie jak Federacyjne Stany Mikronezji w 1986 r. $)^{22}$ - otrzymywana pomoc rozwojowa per capita była również wysoka. Średnia wartość zbliżona jest do pomocy uzyskiwanej przez Tuvalu. W analizowanym 20-letnim okresie waha się ona w przedziale od 616 USD (w 2010 r.) do

\footnotetext{
21 Ibidem.

22 Ibidem.
} 
1779 USD (w 2013 r.). W stosunku do PNB wskaźnik pomocy rozwojowej wynosił od 16,3\% (w 2010 r.) do 53,9\% (w 1996 r.) (patrz rys. 3).

Kolejna z wysp - Palau (powierzchnia $459 \mathrm{~km}^{2}$, populacja 21,3 tys. w $2015 \mathrm{r}$., uzyskanie niepodległości w $1994 \mathrm{r}^{23}$ ) charakteryzuje się inną, wyraźnie spadkową tendencją (patrz rys. 4). Po „rekordowym” wskaźniku ODA/PNB w 1994 r. (242,3\%; 12 tys. USD per capita) w kolejnych latach (objętych badaniem) następuje silne zredukowanie pomocy rozwojowej. Niemniej jednak po 1999 r. pomoc ta była nadal znaczna - jedna $z$ największych na świecie. W przeliczeniu na mieszkańca m.in. w 2008 r. wyniosła ona 2123 USD (patrz rys. 4).

Rysunek 4. Wskaźniki oficjalnej pomocy rozwojowej (ODA) względem produktu narodowego brutto (PNB) oraz ODA per capita na Palau w latach 1995-2014
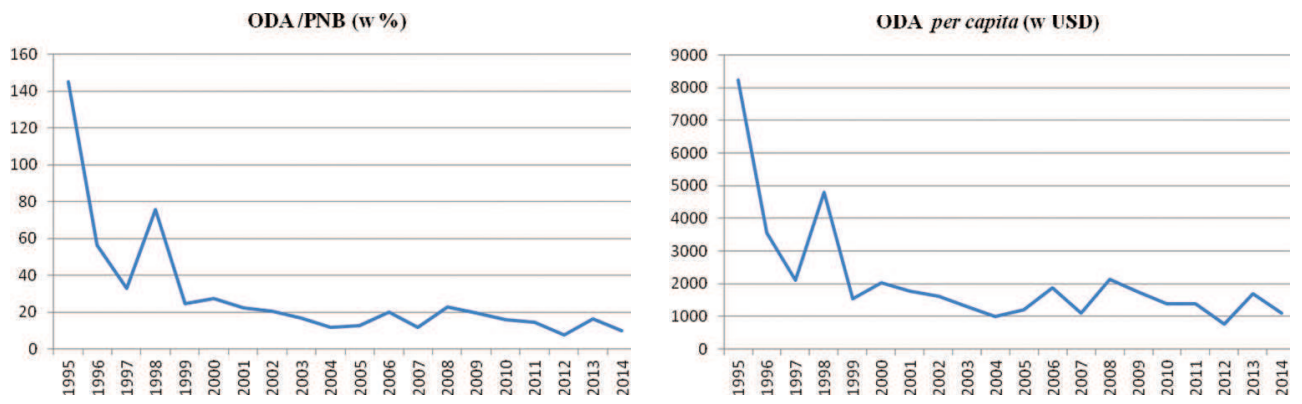

Źródło: Jak do rysunku 1.

Pomoc rozwojowa na Wyspach Salomona - we względnie dużej (jeżeli analizujemy ją z perspektywy SIDS) gospodarce (powierzchnia 28 tys. $\mathrm{km}^{2}$, populacja 622,5 tys. mieszkańców w 2015 r., rok uzyskania niepodległości $1978^{24}$ ) - charakteryzuje się do 2010 r. ogólnym wzrostowym trendem - pogłębieniem procesu „monokultury rozwojowej”. W następnych latach następował jej spadek. Pomoc per capita wahała się w analizowanym 20-letnim okresie w przedziale od 60 USD (w 2002 r.) do 647 USD (w 2010 r.). W stosunku do PNB wynosiła w latach 1995-2014 od 7,4\% (w 1997 r.) do 68,6\% (w 2010 r.) (patrz rys. 5).

Na Wyspach Świętego Tomasza i Książęcej, jedynej spośród analizowanych niepacyficznej SIDS, pomoc rozwojowa charakteryzuje się, pomimo wahań, ogólną tendencją spadkową (patrz rys. 6). Jakkolwiek badane wskaźniki były wysokie - od 146 USD per capita (w 2006 r.) do 669 USD per capita (w 1995 r.) oraz od 11,5\% ODA/PNB

\footnotetext{
23 Ibidem.
}

24 Ibidem. 
(w 2014 r.) do 55,5\% ODA/PNB (w 2001 r.). W ostatnim przypadku (pomimo braku danych) (patrz rys. 6) można założyć, że w latach 1995-2001 ODA/PNB wynosiła znacznie więcej niż 50\%, co wskazuje na dużą skalę pomocy rozwojowej, w tej równie niewielkiej - jak analizowane wcześniej pacyficzne - młodej gospodarce (powierzchnia $964 \mathrm{~km}^{2}$, liczba ludności 194 tys. w 2015 r., uzyskanie niepodległości w 1975 r. $^{25}$ ).

Rysunek 5. Wskaźniki oficjalnej pomocy rozwojowej (ODA) względem produktu narodowego brutto (PNB) oraz ODA per capita na Wyspach Salomona w latach 1995-2014
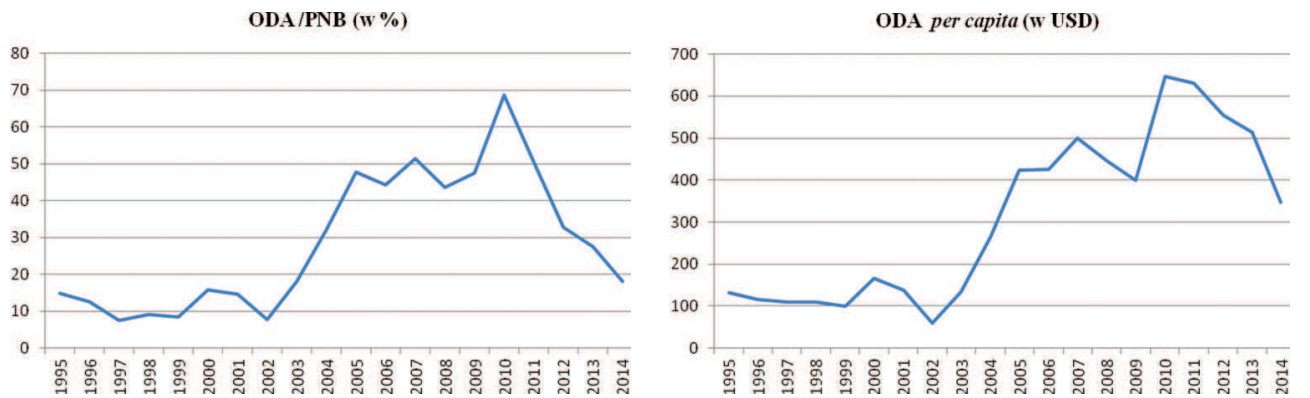

Źródło: Jak do rysunku 1.

Rysunek 6. Wskaźniki oficjalnej pomocy rozwojowej (ODA) względem produktu narodowego brutto (PNB) w latach 2001-2014 oraz ODA per capita w latach 1995-2014 na Wyspach Świętego Tomasza i Książęcej
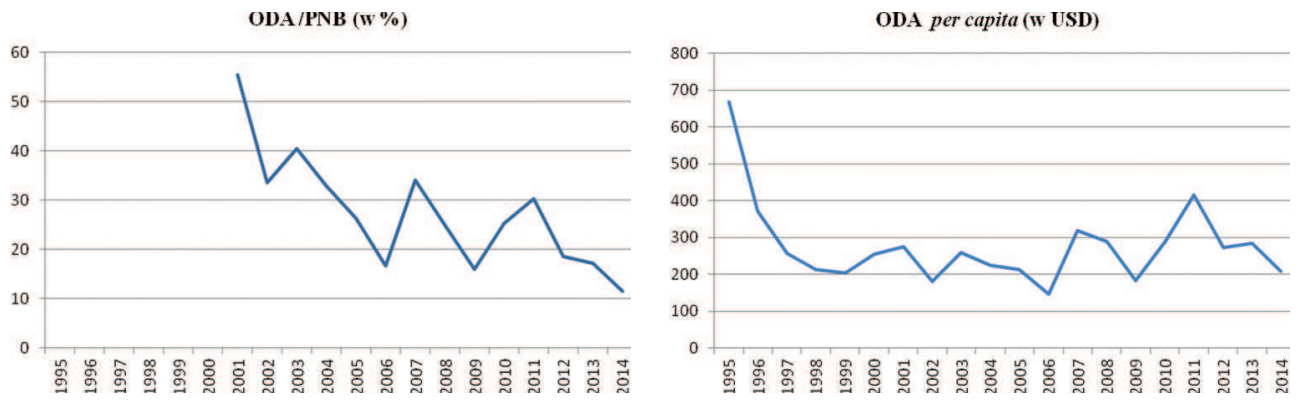

Źródło: Jak do rysunku 1.

$\mathrm{Na}$ ostatniej z analizowanych wysp - Kiribati (powierzchnia $811 \mathrm{~km}^{2}$, liczba mieszkańców 105,7 tys. w 2015 r., uzyskanie niepodległości w 1979 r. ${ }^{26}$ ) - pomoc

25 Ibidem

26 Ibidem. 
rozwojowa, podobnie jak na Tuvalu, wykazywała w latach 1995-2014 ogólną tendencję rosnącą. Pomoc wahała się w przedziale od 145 USD per capita (w 2001 r.) do 716 USD per capita (w 2014 r.). Wskaźnik ODA/PNB natomiast od 10,8\% (w 2004 i 2010 r.) do $27,8 \%$ (w 2011 r.) (patrz rys. 7).

Rysunek 7. Wskaźniki oficjalnej pomocy rozwojowej (ODA) względem produktu narodowego brutto (PNB) oraz ODA per capita na Kiribati w latach 1995-2014
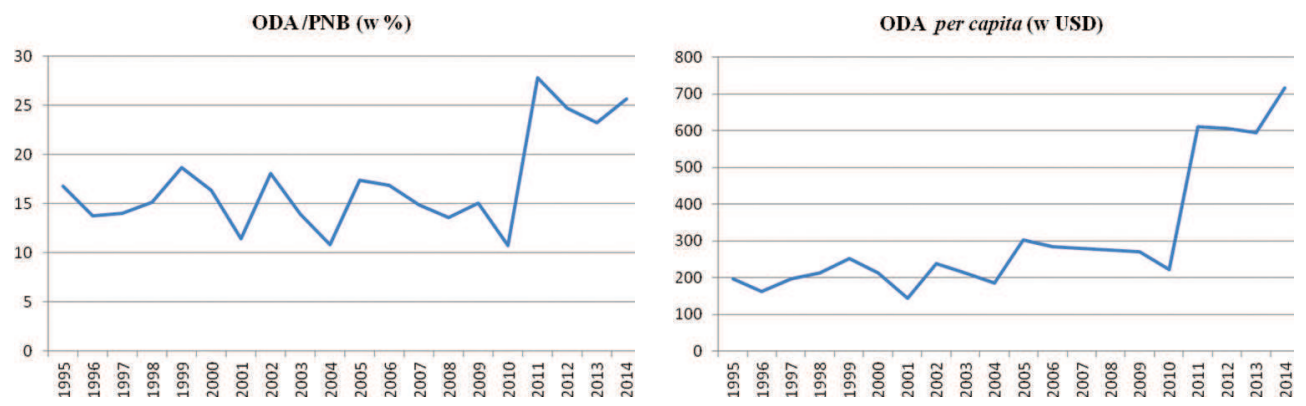

Źródło: Jak do rysunku 1.

Analiza wskaźników pomocy gospodarczej w przeliczeniu na mieszkańca, jak i wielkości pomocy w stosunku do PNB w okresie lat 1995-2014 w przytoczonych sześciu państwach wyspiarskich wyraźnie wskazuje, że pomimo pewnych odmienności cechuje je „monokultura rozwojowa”. Przesłanką takiego stwierdzenia jest wysokość wskaźników oraz ich „trwałość, świadczące o otrzymywaniu znacznych środków pomocowych w długim okresie. Najbardziej jednak obrazowym odzwierciedleniem „uzależnienia” od pomocy rozwojowej badanych gospodarek wydaje się specyficzne „odwzorowanie” kształtu wykresu wskaźnika ODA/PNB i wskaźnika pomocy per capita w danym państwie. Spadek czy wzrost pomocy jest wyraźnie „odwzorowany” w PNB danej gospodarki, świadcząc o symbiotycznym związku pomiędzy tymi wielkościami.

Odpowiedź na postawione na początku rozważań pytanie wydaje się zatem prosta i oczywista. W analizowanych sześciu przypadkach pomoc rozwojowa w znacznym stopniu wywołuje zjawisko „monokultury pomocowej”. Badany 20-letni przedział czasowy, w którym wyraźna jest specyficzna niemożność wyjścia gospodarek ze stagnacji - specyficzne zamknięcie (czy też zakleszczenie) na „pomocowej” ścieżce rozwoju, skłania do stwierdzenia, że zjawisko to jest trwałe. Przeznaczona pomoc w specyficzny sposób - wypierając tradycyjne działy gospodarki (rolnictwo, rybołówstwo, rzemieślnictwo) - „uzależniła” gospodarkę. Stwierdzenie tego faktu skłania do postawienia dalszych pytań, np. czy w ogóle istnieje możliwość „wyrwania się” 
z gospodarczej stagnacji w analizowanej grupie SIDS, skoro pomoc rozwojowa jest nieskuteczna? Czy „zamknięcie” przez środki pomocowe w „błędnym kole monokultury pomocowej” spowodowało, że jest to zjawisko trwale „deformujące” gospodarkę wyspiarską?

\subsection{Modele rozwoju małych gospodarek wyspiarskich a zakleszczenie w monokulturze}

SIDS są osobliwą grupą państw (terytoriów), która charakteryzuje się specyficzną „kruchością" ${ }^{27}$, wynikającą z cech geograficznych (małe rozmiary, ograniczone zasoby naturalne, izolacja, klęski żywiołowe). Determinują one wąską specjalizację i marginalne znaczenie w handlu międzynarodowym. Gospodarki te nie są w stanie wykorzystać efektu skali, uzależnienione są od zewnętrznego sektora usługowego, charakteryzują się niskim stopniem wykorzystania zasobów pracy, kulturową dominacją Północy, wysokimi kosztami transportu, infrastruktury i administracji oraz podatnością na źródła działalności przestępczej (pranie brudnych pieniędzy, narkotyki, korupcja) ${ }^{28}$.

Pomimo posiadania pewnych wspólnych cech nie są one jednolitą grupą pod względem poziomu rozwoju społeczno-gospodarczego ${ }^{29}$. Uwzględniając najprostszy podział, można wyróżnić dwie skrajnie grupy. Pierwsza to wyspy o najwyższym poziomie rozwoju. Do tej grupy należy zaliczyć znaczą część państw subregionu karaibskiego (m.in. Bahamy, Barbados, Antiguę i Barbudę) oraz niektóre wyspy na obszarze Oceanii (m.in. terytoria zależne takie jak: Polinezja Francuska, Nowa Kaledonia, Samoa Amerykańskie oraz niezależne państwo Nauru). W gospodarkach tych dominuje, nakierowany na zaspokojenie zewnętrznego popytu (obrona, biznes, wypoczynek), usługowy charakter. Cecha ta silnie wiąże je z gospodarką światową. Dokonywane są znaczące transfery finansów i technologii, rolnictwo podupada lub całkowicie zanika, dominuje miejski styl życia. Przeciwstawną stanowią najbiedniejsze wyspy - zaliczane również do grupy najsłabiej rozwiniętych państw świata, m.in.: położone na peryferiach Afryki - Wyspy Świętego Tomasza i Książęca oraz Wyspy (Republika) Zielonego Przylądka, na Oceanie Indyjskim - Republika Komorów, na Pacyfiku - Kiribati, Tuvalu, Vanuatu, Wyspy Salomona oraz Wyspy Tonga.

27 Cechę tę literatura anglojęzyczna określa jako vulnerability, co można tłumaczyć jako podatność gospodarki na zranienia (ciosy), niezabezpieczoną przed atakami (ciosami), posiadającą słabe (niezabezpieczone) punkty. Termin ten powszechnie stosowany jest m.in. przez UNCTAD.

28 M. Jasiński, Zrównoważony rozwój..., op.cit., s. 212, 213.

29 Ze względu na ograniczone ramy artykułu przedstawione zostaną tylko wnioski z wcześniejszych badań autora; szerzej patrz M. Jasiński, Kolonizacja turystyczna jako element rozwoju gospodarek wyspiarskich, SGH, Warszawa 2013 (rozprawa doktorska), s. 94-97 i n. 
Są to głównie obszary rolnicze, o skromnych, punktowych transferach z zewnątrz, gdzie liczba ludności szybko rośnie, co staje się impulsem do emigracji.

Odwołując się do pozostałych modeli rozwojowych SIDS $^{30}$, te państwa, które poszły ścieżką turystyczną (model SITE) oraz po osiągnięciu dzięki tej ścieżce wyższego poziomu rozwojowego, ścieżką PROFIT osiągnęły znaczny progres w rozwoju społeczno-gospodarczym, stając się względnie zamożnymi gospodarkami (jak na ograniczające je uwarunkowania). Podążenie ścieżką turystyczną spowodowało jednak specyficzne zjawisko określone w polskiej literaturze przedmiotu „monokulturą turystyczną", w literaturze anglojęzycznej sformułowaniem SITE, będącym akronimem od słów: małe (small - S), wyspiarskie (island - I), gospodarki turystyczne (tourism, economies - TE). Zjawisko to wiąże się ze znacznymi zagrożeniami - jest „przerysowaną", „rozdętą” wersją „turystycznej” choroby holenderskiej ${ }^{31}$.

Rozwój gospodarki turystycznej umożliwił, w części przypadków, przejście na wyższy poziom rozwoju - do „fazy” PROFIT (akronim od: people consideration affecting citizenship, residence and employment rights - $\mathrm{P}$, resources management - $\mathrm{R}$, overseas engagement and international recognition - $\mathrm{O}$, finance, insurance and taxation - FI, transportation - T). Ta utożsamiana jest w literaturze polskiej ze zjawiskiem określanym wieloma terminami - oazą podatkową, rajem podatkowym, tax haven czy off shore financial center. Ujmując ogólnie, sprowadza się ona do specjalizacji w usługach finansowych. W przypadku państw, które są w fazie PROFIT (m.in. Bahamy, Barbados), należy stwierdzić, że nastąpił bardzo znaczny (choć dyskusyjny) progres społeczno-gospodarczy.

Konkludując rozważania dotyczące małych gospodarek wyspiarskich, w dużym uproszczeniu można stwierdzić, że SIDS, podejmując się każdej działalności gospodarczej, z czasem „zakleszczają” się lub silnie się zbliżają do zjawiska „monokultury”, czy też ujmując to inaczej, dotykają je skrajne efekty choroby holenderskiej. Z tym, że „zamknięcie” na ścieżce turystycznej umożliwia rozwój. Zakleszczenie się natomiast na ścieżce „pomocowej” rozwoju jednak nie powoduje, na co wyraźnie wskazują nie tylko dane statystyczne.

Próbując zatem udzielić odpowiedzi na pytanie, czy możliwe jest wyrwanie się z „błędnego koła monokultury rozwojowej” w przypadku SIDS (gospodarujących wg modelu MIRAB), należy stwierdzić, że teoretycznie tak - gospodarki te mogą przełamać stagnację i naśladując wzorzec bogatszych SIDS, mogą podążyć ścieżką turystyczną (ze wszelkimi konsekwencjami i niebezpieczeństwami z niej wynikającymi).

30 Szerzej patrz M. Jasiński, Teoria zależności od ścieżki a małe gospodarki wyspiarskie, „Zeszyty Naukowe KGŚ SGH” nr 28, Oficyna Wydawnicza SGH, Warszawa 2010, s. 52-72.

31 Szerzej patrz M. Kachniewska, A. Niezgoda, A. Pawlicz, op.cit., s. 215-222. 
Uwarunkowania społeczne, historyczne oraz naturalne - chociażby sam fakt położenia geograficznego (znaczne odległości od głównych wysyłających rynków turystycznych) powodują, że „turystyczna” specjalizacja, pomimo „kurczenia się świata”, wydaje się dla wielu SIDS, będących w fazie „monokultury pomocowej”, nadal odległa.

\section{3. „Monokultura rozwojowa" w państwach wyniszczonych konfliktami}

Pozostał, w kontekście „monokultury rozwojowej”, jeszcze jeden z wątków, który ze względu na ograniczone ramy artykułu nie został poruszony, a wymaga chociażby zasygnalizowania. Jest to kwestia innych, niewyspiarskich państw, w których skrajna „pomocowa” choroba holenderska występuje. Do tej grupy należy zaliczyć m.in. „słabych i wyniszczonych konfliktami”32: Liberię, Afganistan, Gwineę Bissau, Burundi, Malawi, Mozambik, Ruandę czy Sierra Leone. Państwa, w których wskaźniki ODA/PNB i ODA per capita, podobnie jak w analizowanych małych gospodarkach wyspiarskich, są bardzo wysokie.

W wymienionych państwach problem „monokulturowości” pomocy rozwojowej jest odmienny (i niewątpliwie bardziej skomplikowany do analizy) niż w gospodarkach MIRAB. W przypadku tych ostatnich u podstawy problemów rozwojowych leżą głównie uwarunkowania geograficzne (jakkolwiek należy zwrócić uwagę, że problem konfliktów zbrojnych dotyka również niektóre gospodarki wyspiarskie, m.in. część obszarów na Oceanii czy karaibskie Haiti). W przypadku tych pierwszych - czynnik ludzki. Dlatego też z perspektywy analizy zjawiska „monokultury pomocowej” „słabi i wyniszczeni konfliktami” wydają się być nieco odmiennym problemem badawczym.

\section{Podsumowanie}

Przedstawiona analiza teoretycznych zagrożeń wynikających ze zjawiska choroby holenderskiej wywołanej przez pomoc rozwojową stanowiła pretekst do zastanowienia się nad ekstremalnym stadium "pomocowej” choroby holenderskiej. Zjawisko to - określone na potrzeby rozważań „monokulturą pomocową" - zostało wyróżnione

32 Por. D. Kopiński, op.cit., s. 187, 188. 
na podstawie analizy wysokości dwóch wskaźników: odsetka oficjalnej pomocy rozwojowej (ODA) w PNB oraz ODA per capita.

Spośród państw o najwyższych wskaźnikach na świecie wyróżniono grupę sześciu małych państw wyspiarskich - pacyficzne: Federacyjne Stany Mikronezji, Tuvalu, Wyspy Marshalla, Palau, Wyspy Salomona, Kiribati oraz afrykańskie: Wyspy Świętego Tomasza i Książęca. Na podstawie teoretycznych rozważań (w oparciu o model MIRAB) i obserwacji wielkości wymienionych wskaźników w sześciu małych państwach wyspiarskich (w latach 1995-2014) stwierdzono, że otrzymywana (w znacznych wielkościach) pomoc rozwojowa doprowadziła do regresu (wyparcia) tradycyjnych dla tych obszarów działów gospodarki (rolnictwa, rybołówstwa, rzemiosła). W konsekwencji do wystąpienia zjawiska „monokultury pomocowej” oraz specyficznego „Zakleszczenia” na pomocowej ścieżce rozwoju. Trwałość zjawiska „monokultury pomocowej” - specyficzne „uzależnienie” funkcjonowania tych gospodarek od pomocy rozwojowej - skłoniła do teoretycznego zastanowienia się, w oparciu o doświadczenia innych małych gospodarek rozwijających się (o inne modele rozwoju SIDS), nad możliwościami przełamania stagnacji i przyspieszenia rozwoju społeczno-gospodarczego. Teoretycznie możliwość tę stanowi rozwój sektora turystycznego.

Konkludując, wstępna analiza „monokultury pomocowej” umożliwia stwierdzenie, że w perspektywie skuteczności pomocy rozwojowej jest to niewątpliwie ciekawe zjawisko, wymagające dalszych, pogłębionych badań. W przypadku tego zjawiska mamy do czynienia ze zdumiewającym paradoksem: im obficiej płyną środki pomocowe do danego kraju, tym bardziej rośnie prawdopodobieństwo, że będzie się on wolniej rozwijał.

\section{Literatura}

Begg D., Fisher S., Dornbusch R., Makroekonomia, Polskie Wydawnictwo Ekonomiczne, Warszawa 2007.

Bertram G., „Sustainable Development” in Pacific Micro-economies, „World Development” Vol. 14, No. 7, 1986, s. 809-822.

Bertram G., Waters R.F., The MIRAB economy in South Pacific microstates, „Pacific Viewpoint" No. 26(3), 1985, s. 497-519.

Bertram G., Waters R.F., The MIRAB process: earlier analyses in context, „Pacific Viewpoint" No. 27(1), 1986, s. 47-59.

Brahmbhatt M., Canuto O., Vostroknutova E., Dealing with Dutch Disease, „Economic Premise" Vol. 16, World Bank 2010, s. 1-3. 
Budnikowski A., Międzynarodowe stosunki gospodarcze, Polskie Wydawnictwo Ekonomiczne, Warszawa 2006.

Capó J., Font A.R., Nadal J.R., Dutch Disease in Tourism Economies: Evidence from the Balearics and the Canary Islands, „Journal of Sustainable Tourism” Vol. 15, No. 6, 2007, s. 615-627.

Corden W.M., Booming Sector and Dutch Disease Economic: Survey and Consolidation, „Oxford Economic Papers” Vol. 36, No. 3, 1984, s. 359-380.

Corden W.M., Neary J.P., Booming Sector and De-industralization in a Small Open Economy, „Economic Journal” Vol. 92, 1982, s. 825-848.

Crocombe R., The South Pacific, University of South Pacific, Suva 2001.

http://data.worldbank.org/

http://www.cia.gov/library/publications/resources/the-world-factbook/

Jasiński M., Kolonizacja turystyczna jako element rozwoju gospodarek wyspiarskich, SGH, Warszawa 2013 (rozprawa doktorska).

Jasiński M., Teoria zależności od ścieżki a małe gospodarki wyspiarskie, „Zeszyty Naukowe KGŚ SGH” nr 28, Oficyna Wydawnicza SGH, Warszawa 2010, s. 52-72.

Jasiński M., Turystyka a małe gospodarki wyspiarskie, „Zeszyty Naukowe KGŚ SGH” nr 23, Oficyna Wydawnicza SGH, Warszawa 2008, s. 195-218.

Jasiński M., Zrównoważony rozwój w monokulturowych gospodarkach turystycznych, [w:] Zrównoważony rozwój turystyki, red. S. Wodejko, Oficyna Wydawnicza SGH, Warszawa 2008, s. 209-226.

Kachniewska M., Niezgoda A., Pawlicz A., Globalizacja i internacjonalizacja działalności turystycznej, [w:] Rynek turystyczny. Ekonomiczne zagadnienia turystyki, red. M. Kachniewska, E. Nawrocka, A. Niezgoda, A. Pawlicz, Wydawnictwo Wolters Kluwer Polska, Warszawa 2012, s. 215-222.

Kopiński D., Pomoc rozwojowa. Teoria i polityka, Difin, Warszawa 2011.

Nkusu M., Aid and the Dutch Disease In Low-Income Countries: Informed Diagnoses for Prudent Prognoses, „IMF Working Paper” 4(49), 2004, s. 1-18.

Nowa Europa, red. D. Rosati, Instytut Wschodni, Warszawa 2007.

Rybczynski T.M., Factor Endowment and Relative Commodity Prices, „Economica, New Series" Vol. 22, No. 88, 1955, s. 336-341.

„The Economist” November 26, 1977, s. 82-83.

Treadgold M.L., Breaking out of the MIRAB mould: historical evidence from Norfolk Island, „Asia Pacific Viewpoint” Vol. 40, No. 3, 1999, s. 237-244. 


\section{Monoculture aspects of the aid Dutch disease}

The article considers theoretical threats of Dutch disease caused by official development aid (ODA), particularly its extreme stage called "aid monoculture". The study presented in the article is an introduction to further research devoted to a wider issue of effectiveness of ODA.

Keywords: Dutch disease, development aid, small island states.

\section{Les aspects monoculturels du syndrome hollandais}

Larticle présente, du point de vue théorique, les dangers du syndrome hollandais qui peuvent être causés par l'aide publique au développement (APD). En particulier, son stade extrême appelé «monoculture d'aide». L'étude présentée dans l'article est une introduction à une recherche plus approfondie consacrée à la question d'efficacité de l'APD.

Mots-clés: syndrome hollandais, aide au développement, petits États insulaires.

\section{Монокультурные аспекты голландской болезни, вызванной официальной помощью по развитию}

В статье рассматриваются теоретические угрозы возникновения голландской болезни, вызванной официальной помощью по развитию (ОПР), в частности ее экстремальной стадии, называемой «монокультурой помощи». Работа является введением к дальнейшим исследованиям, посвященным более широкой проблеме эффективности ОПР.

Ключевые слова: голландская болезнь, помощь в целях развития, малые островные государства. 